\title{
Non-Thermal Production of Pure Hydrogen from Biomass: HYVOLUTION
}

P.A.M. Claassen, T. de Vrije, E.G. Koukios, E.W.J. van Niel, E. Özgür, İ. Eroğlu, I. Nowik, M. Modigell, W. Wukovits, A. Friedl, D. Ochs, W. Ahrer

This document appeared in

Detlef Stolten, Thomas Grube (Eds.):

18th World Hydrogen Energy Conference 2010 - WHEC 2010

Parallel Sessions Book 2: Hydrogen Production Technologies - Part 1

Proceedings of the WHEC, May 16.-21. 2010, Essen

Schriften des Forschungszentrums Jülich / Energy \& Environment, Vol. 78-2

Institute of Energy Research - Fuel Cells (IEF-3)

Forschungszentrum Jülich $\mathrm{GmbH}$, Zentralbibliothek, Verlag, 2010

ISBN: 978-3-89336-652-1 


\title{
Non-Thermal Production of Pure Hydrogen from Biomass: HYVOLUTION
}

\author{
Pieternel A.M. Claassen, Truus de Vrije, Emmanuel G. Koukios, Ed W.J. van Niel, \\ Ebru Özgür, İnci Eroğlu, Isabella Nowik, Michael Modigell, Walter Wukovits, Anton \\ Friedl, Dominik Ochs, and Werner Ahrer
}

\begin{abstract}
HYVOLUTION is the acronym for the Integrated Project (IP) "Non-Thermal Production of Pure Hydrogen from Biomass," which was defined in the 6th EU Framework Programme on Research, Technological Development and Demonstration, Priority 6.1 Sustainable Energy Systems. This IP started on 1 January 2006 and will end on 31 December 2010. Its aim, "Development of a blueprint for an industrial bioprocess for decentral hydrogen production from locally produced biomass," adds to the number and diversity of hydrogen production routes giving greater security of supply at the local and regional level. Moreover, this IP contributes a complementary strategy to fulfill the increased demand for renewable hydrogen expected in the transition to the Hydrogen Economy. The novel approach adopted in the project is based on a combined bioprocess employing thermophilic and phototrophic bacteria, to provide the highest hydrogen production efficiency in small-scale, cost-effective industries. In HYVOLUTION, 10 EU countries, Turkey, Russia, and South Africa are represented to assemble the critical mass needed to make a breakthrough in costeffectiveness.
\end{abstract}

\section{Copyright}

Stolten, D. (Ed.): Hydrogen and Fuel Cells - Fundamentals, Technologies and Applications. Chapter 8. 2010. Copyright Wiley-VCH Verlag GmbH \& Co. KGaA. Reproduced with permission. 